Милена Ивановић

Универзитет у Београду

Филолошки факултет

Катедра за славистику

ivanovic.milena@gmail.com
УДК 81'25:811.161.1'373.232.2

https://doi.org/10.18485/slavistika.2019.23.2.9

Оригинални научни рад примљено 12.07.2019.

прихваћено за штампу 10.10.2019.

\title{
ПРОБЛЕМИ ПРЕВОЪЕЊА ВЛАСТИТИХ ИМЕНА: ПАТРОНИМИ (на материјалу руског језика)
}

У раду се разматрају проблеми преношења источнословенских патронима, као својеврсних реалија, приликом превођења на српски језик. Анализирају се постојећи преводи и предочавају могућности примене не само транскрипције, већ и других поступака, којима се омогућава преношење различитих функција патронима у тексту и различитих елемената њиховог садржаја у циљу постизања максималне еквиваленције текста оригинала и текста превода. Део рада посвећен је начинима превођења саме лексеме отчество.

Кључне речи: патроним, реалија, функција идентификације, емоционална функција, транскрипција, прагматичка адаптација, функционална замена, експликација, преводилачки коментар, додавање.

This article deals with the translation of Eastern Slavic patronymics, as a form of realia, to Serbian. We analyze existing translations and present possibilities of applying not only transcription, but also other procedures, which allows the transmission of various functions of patronymics in the text and various elements of their content in order to achieve maximum equivalence between the original text and the translated text. A part of the paper is devoted to the ways of translating the word отчество.

Key words: patronymic, realia, identification function, emotional function, transcription, pragmatic adaptation, functional replacement, explanation, translator's notes, addition.

Властита имена представљају посебан слој лексике сваког језика који се од осталих лексема, односно апелатива, разликује на семантичком и формалном плану. Специфичне формалне (нпр. крња парадигма броја, посебности промене појединих властитих имена, типични творбени модели) и семантичке (природа везе у којој властито име стоји са појмом односно објектом који номинује) ${ }^{1}$ карактеристике онима мање-више су од секундарног значаја за теорију и праксу превођења. Од примарног је, пак, значаја функција властитог имена.

Специјализована функција онима, по својој суштини екстралингвистичка, јесте функција идентификације једног одређеног конретног објекта (референта) ванјезичке стварности. Основни задатак преводиоца је у том смислу јасан: властито име треба да за реципијента превода обезбеди идентификацију истог рефернта ванјезичке стварности. Овај задатак најчешће се решава применом транскрипције као уобичајеног поступка за преношење ове врсте језичких јединица.

Када се говори о транскрипцији као преводилачком поступку, на првом месту се наводе имена као типичан случај његове примене (ОПП 2010: 202-

${ }^{1}$ О различитим приступима семантици властитих имена в. монографију А. Суперанске (Суперанская 1973: 45-90). 
203, DTS: 175). О примени овог поступка приликом превођења са словенских језика доста је писано, а посвећен му је и добар део славистичког зборника Транскрипиија и превођење са словенских језика (Маројевић: 1988). Правопис српскога језика садржи посебно поглавље - „Особености транскрипције словенских имена“, које се у новим издањима допуњава и коригује. Иако би се о неким питањима транскрипције и даљег адаптирања словенских nomina propria могло дискутовати ${ }^{2}$, ми ћемо се у овом раду бавити могућностима примене других поступака (самостално или у комбинацији с транскрипцијом) при превођењу једне врсте властитих имена у циљу преношења како њихове функције идентификације, тако и других елемената њиховог садржаја. Ови поступци готово да нису улазили у сферу интересовања славистичке транслатологије код нас 3 . Предмет овог рада биће источнословенски (руски) патроними, за чије је превођење битна још и чињеница да за српску културу и језик представљају својеврсну реалију (в. о томе ниже), мада и све друге врсте онима имају своје специфичности које у процесу превођења увелико надилазе проблеме правилне транскрипције и адаптације.

Као и код било које друге врсте јединица превођења, и код властитих имена избор поступка условљен је врстом текста у којем су она употребљена. У основи традиционалне поделе врста превођења на књижевно и стручно (некњижевно) лежи врста, односно намена текста који се преводи (Сибиновић 2009: 66). Оними, зависно од врсте текста у којима се срећу, могу, осим своје основне функције идентификације, односно референцијалне функције, која је карактеристична за све текстове, имати и друге функције - емоционалну, која се реализује, на пример, при обраћању у таквим стручним типовима текста као што су писмо, приватно или пословно, или у књижевном тексту (употреба различитих антропонима или њихових комбинација, односно обраћање само по имену, само по презимену, по имену и патрониму, употреба надимака, хипокористика и сл.) или и емоционалну и естетску у књижевним делима. Полазећи од врсте текста и функције властитог имена у њему, преводилац бира поступак који ће у сваком конкретном случају применити.

Говорећи о функцијама властитих имена, А. Суперанска истиче да антропоними у односу на друге врсте онима имају специфичну и специјалну функцију „друштвене легализације личности“ (Суперанская 1973: 274). Оваква функција посебно долази до изражаја приликом превођења докумената физичких лица - пасоша, различитих извода, потврда, диплома и слично. Сврха превођења оваквих докумената јесте остваривање одређених социјалних права, а властита имена у њима, поред осталих података (датум рођења, матични или неки други идентификациони број и сл.), прво су средство идентификације личности.

${ }^{2}$ Рецимо, контрадикторно решење према коме актуелни правопис прописује преношење украјинског и белоруског фарингалног $[\mathrm{h}]$ транслитерацијом као $Г$, док се русинско у поступку транскрипције замењује графемом X која означава њему најближи српски глас.

${ }^{3}$ Издваја се један рад пољског слависте В. Лубаса у коме се он дотакао неких аспеката преношења властитих имена у књижевним текстовима (Лубас 1970). У совјетској и руској теорији превођења, с друге стране, проблемима преношења властитих имена, махом са западноевропских језика на руски, посвећен је већи број радова или поглавља у монографијама (Виноградов 2001, Влахов, Флорин 1970, Алексеева 2004, Ермолович 2001). 
Веродостојност превода ових текстова обично се потврђује овером а превод се спаја са оригиналним текстом како би службена лица могла да их упореде. Овај екстралингвистички фактор одређује задатак преводиоца - пренети властито име тако да оно по својој форми што мање одступа од изворног облика - и условљава избор поступка - транскрипцију, уз евентуалну транслитерацију или навођење изворног облика графемама језика оригинала, који се обично даје у загради. За једну врсту личних имена, која ће се у другим типовима текста преносити најчешће транскрипцијом, примена транскрипције, међутим, није пожељна при превођењу ове врсте текстова на српски језик. Реч је о источнословенским патронимима, који представљају један део трочланог личног имена и заједно са именом и презименом имају функцију прецизне правне идентификације личности. Будући да у савременом српском језику ова врста онима не постоји, преношење патронима транскрипцијом може створити нетачну представу да се ради о двоструком презимену или уопште изазвати недоумицу службених органа којима је превод документа намењен и, у крајњем случају, отежати идентификацију и легализацију личности, поготово ако узмемо у обзир да се у украјинском и белоруском пасошу (а пасош је основни идентификациони документ странца) патроним уопште не наводи, а у руском наводи, али за разлику од имена и презимена не транскрибује латиницом, будући да је латинична транскрипција намењена страној земљи, за коју је патроним правно ирелевантан. Како би функција превода одговарала функцији оригинала, патроним у званичним документима треба да буде замењен својим функционалним аналогом у српским исправама - конструкцијом од оца и именом оца (које и лежи у основи патронима) у облику генитива или навођењем имена оца у загради или између зареза иза имена, јер управо наведено на један од ова три начина име оца представља додатно средство идентификације у овој врсти текстова у српском језику: Иван Иванович Иванов: Иван Иванов од оца Ивана, Иван (Иван) Иванов, Иван, Иван, Иванов.

Као типична црта источнословенског језичког простора и друштва, културе Руса, Украјинаца и Белоруса, патроними представљају својеврсну реалију․․ Под термином реалија у теорији превођења подразумевају се речи које означавају предмете, појмове или ситуације који не постоје у практичном искуству људи који говоре други језик (Бархударов 1975: 95, ОПП 2010: 166), односно такви елементи текста који, означавајући предмете, појмове или појаве карактеристичне за одређено географско окружење, културу, свакодневни живот или социјално-историјске околности одражавају национални и историјски колорит (Влахов, Флорин 1970: 5, DTS: 139-140). Употребљени у књижевном тексту, па и у појединим врстама стручних текстова (на пример, у публицистици) патро-

${ }^{4}$ В. Виноградов сматра да су сва властита имена увек реалије. „Она у говору именују постојећи или измишљени објекат мишљења, лице или место, који су јединствени и непоновљиви“ (Виноградов 2001: 150). У том смислу оними садрже информације о националној или локалној припадности, о вери, одражавају бројне аспекте живота народа, могу изазивати одређене асоцијације недоступне говорницима других језика и представницима других култура, које често остају „изгубљене у преводу“. А. Суперанска истиче да имена садрже „етнографске, историјске, географске, социолошке, књижевне компоненте“ (Суперанская 1973: 7). Патроними међу њима заузимају посебно место као врста антропонима без аналога у многим језицима. 
ними као специфична врста реалија осим когнитивне функције идентификације представљају и средство реализације експресивне функције претежно повезане са њиховим националним колоритом, мада у основи експресије могу бити и други елементи. Стога је њихово преношење транскрипцијом, као основним поступком који се примењује при преношењу таквих јединица превођења као што су реалије ${ }^{5}$, у овој врсти текстова не само оправдано, већ и неопходно.

Од осталих поступака који се примењују при преношењу реалија на патрониме су применљиви и употреба функционалног аналога, као и експликација. Последња се увек комбинује са транскрипцијом и, по правилу, наводи ван текста у виду преводилачког коментара. Овакав коментар при превођењу на српски обично није потребан, будући да је патроним као саставни део руског личног имена српској читалачкој публици добро познат из бројних превода руске књижевности. Функционални аналог може, пак, бити средство преношења једне друге функције патронима, коју је српском читаоцу теже да докучи. Наиме, у источнословенским језицима патроними се заједно са именом употребљавају као форма учтивог обраћања саговорнику (у књижевности - у репликама јунака) или именовања трећег лица (у књижевном тексту - у репликама јунака и пишчевом говору) и као такви представљају средства изражавања емоционалне функције. Име и патроним употребљавају се када између саговорника постоји разлика у узрасту или социјалном положају, у комуникацији подређеног и надређеног на радном месту, у обраћању ученика наставнику, студената професору и у различитим другим ситуацијама узрасне или социјалне неједнакости саговорника. У српској говорној етикецији зависно од ситуације користе се различити начини обраћња, на пример чика, тетка, тета са именом у обраћању млађих старијима у неслужбеној комуникацији, господине, госпођо, госпођице са именом или презименом у службеној комуникацији; често се саговорник не ословљава именом или презименом већ само титулом, звањем и слично - докторе, професоре, наставниче, учитељице, директоре, шефе, колега или титулом и презименом - докторе Павловићу, професоре Петровићу итд. Све су ово функционални аналози источнословенског обраћања по имену и патрониму који могу бити употребљени у преводу применом поступка тзв. функционалне замене, као својеврстан вид прагматичке адаптације текста превода, како би била очувана емоционална функција исказа. Циљ прагматичке адаптације јесте приближавање текста реципијенту који припада другом језичком колективу, другој култури (Комиссаров 2002: 141), али истовремено представља удаљавање од културе оригинала, брише национални колорит текста, чиме се смањује степен еквиваленције превода оригиналу. Као својеврстан културни маркер у књижевним текстовима функционишу и патроними. Међутим, они нису једини такав маркер и њихова замена функционалним аналозима у појединим деловима текста не мора битно мењати степен еквиваленције. Комбинацијом једног и другог поступка преводилац може успо-

${ }^{5}$ Поред транскрипције, Влахов и Флорин издвајају и следеће поступке: калкирање, полукалкирање, асимилацију, семантички неологизам, адаптацију, приближан превод у који убрајају генерализацију, конкретизацију, функционални аналог и експликацију, као и тзв. контекстуални превод (Влахов, Флорин 1970: 93), чији су избор и примена условљени пре свега врстом реалије и типом текста. 
ставити равнотежу између културолошке и емоционалне функције патронима, а избор може зависити и од претпостављеног реципијента превода - потреба за прагматичком адаптацијом већа је, рецимо, код текстова намењених млађим читаоцима. Прагматичка адаптација може се вршити и у стручним текстовима - рецимо, у обраћању на почетку писма (поготово при превођењу са српског на источнословенске језике) или при усменом превођењу.

Како показује наша анализа, овај се поступак у преводима на српски практично не примењује, чак ни онда када је у питању књижевност за децу, ни у старијим ни у новијим преводима. Српски читалац, дакле, најчешће остаје ускраћен за имплицитне конотативне елементе значења патронима у садржају оригинала. Тако, на пример, превод фрагмента из Солжењициновог романа Један дан у животу Ивана Денисовича: „Иди, бригадир! Иди, ты там нужней! - (Зовет Шухов его Андрей Прокофьевичем, но сейчас работой своей он с бригадиром сравнялся (...)“ у коме елементи смисла на које је и сам писац указао у коментару нису експлицирани: „- Иди, бригадиру! Иди, ти си тамо потребнији! - (Шухов га иначе зове Андреј Прокофич, али се он у овом тренутку, својим радом, изједначио с бригадиром)“ (Solženjicin 2006: 89) може српском читаоцу остати нејасан. Ови елементи, могли би се, рецимо, пренети у тексту превода поступком додавања синтагми типа с извесном дозом поштовања / уважавања, нпр. Шухов га иначе с извесном дозом поштовања ословљава са Андреј Прокофич... и слично.

Патроними имају и краћу форму. Њена употреба ограничена је разговорним стилом, одакле је продрла и у књижевност, пре свега у реплике јунака, мада се може срести и у пишчевом говору. Скраћени патроними лишени су социјалне конотације, имају дозу учтивости али без елемената званичног обраћања. Дистанца између особа при коришћењу скраћеног облика мања је него при употреби пуног, ове форме обично функционишу у комуникацији између добрих пријатеља и старих познаника, вршњака, углавном између мушкараца. Скраћени облик патронима чешће од пуног се користи самостално, без имена, и тада је елемент фамилијарности још израженији, а дистанца мања. Све наведене компоненте семантике ове форме обраћања, које читалац оригинала с лакоћом препознаје, нестају у преводу при преношењу транскрипцијом. С друге стране, овде је тешко наћи функционални еквивалент који би истовремено преносио и дозу поштовања и спонтан, присан, фамилијаран однос. Такви аналози могле би бити лексеме и синтагме као што су пријатељу, друже, стари, стари друже, стари мој и слично, самостално или у комбинацији са скраћеним именом или скраћеним патронимом. И овде свакако треба успоставити равнотежу између национално-културолошких и других елемената оваквог вида ословљавања. Решење може бити и преводилачки коментар, мада он, с обзиром да нарушава структуру текста и тиме умањује његов естетски утицај на читаоца, представља крајње средство коме преводилац прибегава само када су све друге могућности исцрпљене 6 . Тако преводилац М. Лалић користи коментар да објасни употребу обраћања у форми Иване Денисичу која се паралелно употребљава са пуним обликом Иван Денисович, који фигурира и у наслову Солжењициновог рома-

\footnotetext{
${ }^{6}$ Ово, уосталом, важи и за превођење било којих других језичких јединица.
} 
на $^{7}$. Коментар се даје при првом помињању скраћеног патронима: „У говорном језику често се код Руса скраћује 'очество', које се при обраћаюу по правилу користи" (Solženjicin 2006: 22). Преводилац је, с једне стране, практично приморан на коментар, будући да краћи облик контрастира са дужим у наслову. C друге стране, коментар се овде може посматрати и као део опште преводиочеве стратегије будући да се среће на више места у тексту. У сваком случају, он читаоца упућује само на сферу употребе - „говорни језик“, док остали аспекти скраћеног патронима, као и патронима уопште, о којима се такође говори у коментару, уопште нису одражени. За разлику од поступка експликације, описног превода датог у самом тексту, који мора бити што сажетији, његова подврста у виду коментара ван текста може бити дужа и максимално информативна, о чему преводилац треба да води рачуна уколико се већ одлучио за коментар.

Поменули смо већ да се патроними у књижевном тексту могу сретати и у пишчевом говору. Овде поред културолошке функције, карактеристичне и за друге ониме, поред указивања на узраст или социјални статус ${ }^{8}$, употреба патронима може одражавати и позитиван (наклоност) или негативан (иронија, подсмех) став писца према јунаку кога именује. Тако, именујући јунаке приче Мали неваљьалаи (Злой мальчик) Чехов иронише над младим заљубљеним паром, представљајући младића и девојку именом, патронимом и презименом Иван Иваныч Лапкин и Анна Семеновна Замблиџкая. Ова иронија, заснована на неуобичајеној употреби патронима, појачана краћом формом Иваныц, остаје без израза у преводу (Чехов 1966) у коме се транскрипција примењује као једини поступак, мада би могла делимично бити пренета поступком додавања лексема као што су господин, господичић или госпођица, госпојииа, господична.

Приликом превођења на српски језик проблем за преводиоце представља и сама лексема отчество. Као еквивалент ове лексеме у Руско-српскохрватском речнику Б. Станковића наводи се синтагма име по оиу (РСР: 510) а у Рускохрватском речнику Р. Ф. Пољанеца синтагма име по оиу и термин патронилик (RHR: 698). Термин је у књижевним текстовима неприхватљив, а уместо синтагме добијене описним преводом - име по оиу, преводиоци, онда када се одлуче за директни превод, користе другачију експликацију, најчешће очево име

${ }^{7}$ Облик Иван Денисыч појављује се у тексту двоструко чешће (16 пута) него Иван Денисович (8 пута и једном у наслову). Краћи облик среће се у репликама других логораша (при обраћању) и тек двапут у пишчевом говору, оба пута када говори о односу Ивана Денисовича и осталих. У оба случаја кратка форма говори о уважавању и истовремено одређеном степену блискости између других логораша и главног јунака. Пуна форма, која се чешће среће у пишчевом говору, функционише као нека врста неутралне позадине на којој се истиче експресивност краће. Поменимо и то да писац свог јунака најчешће именује „званично“, по презимену Шухов, што одговара околностима и месту на коме се одвија радња. Презиме као начин именовања у тексту се среће више од 400 пута, од тога само једном при обраћању. Овако га ословљава капетан Бујновски, што одговара типичној форми ословљавања у војсци и морнарици. Многе од ових нијанси, доступних читаоцу оригинала, у преводу нестају.

${ }^{8}$ Употреба пуних патронима на виши друштвени статус, скраћених на нижи, на пример. Овакву конотацију могу имати и деминутивно-хипокотистичке форме имена, употреба само презимена и сл. Детаљнију анализу функционисања антропонима у књижевном делу на примеру Чеховљевог стваралаштва в. нпр. код Д. О. Мачиљске (Мачильска 2018). 
(нпр. М. Лалић у преводу Једног дана из живота Ивана Денисовича, М. Чехова и В. Стевановић у два различита превода Гогољевог Портрета, В. Дмитријев у преводу Толстојевог Васкрсеља), примењујући уз то и поступак додавања уз превод лексеме имя, то јест имя и отчество преводе као крштено и очево име (нпр. М. Јовановић у преводу Булгаковљевог Псећег сриа и Толстојевог Васкрсеґа). Љ. Максимовић у преводу Коцкара Достојевског као еквивалент за синтагму имя и отчество бира пуно име. У старијим преводима срећемо и еквивалент очинство (М. Јанковић у преводу Толстојеве Младости).

Понекад преводиоци успешно примењују поступак функционалне замене: „(...) расскажет о том, (...) кто был начальник дивизии, и как его звали по имени и отчеству“ - „прича ко је био командант дивизије и како се звао“ (Dostojevski 1981: 258, превод М. Бабовића) или изостављања: „Извините, как вас по имени-отчеству, я забыл?“ - „Извините, како вам оно беше... ја сам заборавио?"“ (Достојевски 2006: 213, превод Ј. Максимовића).

Колико је превођење лексеме отчество проблематично за преводиоце показује пример превода Гогољевог Портрета (Gogolj 1948) у коме га преводилац В. Стевановић у једном фрагменту текста преводи као очево име, а у следећем једноставно изоставља читаву реченицу: „Фраза «Виват, Андрей Петрович!» также очень понравилась; печатным образом называют его по имени и по отчеству - честь, доныне ему совершенно неизвестная“, која је „незгодна“" и с обзиром на метатекст (сведен, заправо, на једну реч - честь) који објашњава емоционалну функцију патронима у именовању и обраћању. Изостављање понекад може бити и прихватљиво решење. Тако, на пример, горенаведена фраза Извините, как вас по имени-отчеству, я забыл? може бити преведена и као: Извините, како вам је име, заборавио сам?

За анализу су занимљива решења П. Дајића у преводу Псећегсриа М. Булгакова (Bulgakov 2008: 66). Преводећи одломак у коме професор Преображенски, доктор Борментаљ и пас-човек Шариков расправљају управо о адекватном начину ословљавања, у коме се реч отчество помиње три пута, преводилац је сваки пут преводи другачије: ,-- Борменталь! / - Нет, уж вы меня по имени и отчеству, пожалуйста, называйте!/ Отозвался Борменталь, меняясь в лице. (...) - Ну и меня называйте по имени и отчеству! - совершенно основательно ответил Шариков./ - Нет! - загремел в дверях Филипп Филиппович, - по такому имени и отчеству в моей квартире я вас не разрешу называть“. У првој реплици, Дајић преводи отчество као презиме: „Ви треба да ме зовете по имену и презимену, молим вас, а не тако!“. Овакав превод није ни адекватан ни еквивалентан. Превођење приближним еквивалентом тзв. аналогом, који се примењује како би се код читаоца створила оријентациона представа о карактеру неке појаве (Бархударов 1975: 101), овде није прихватљиво јер доктор Борментаљ управо не жели да му се Шариков обраћа (само) по презимену, што је неучтив начин обраћања супротан поштовању које проистиче из обраћања по имену и патрониму. Овде би се, заправо, могла применити једна друга врста замене, конкретизација у којој би смо уместо имя и отчество навели конкретно Иван Арнолдович, уз евентуално додавање које би указивало на елемент учтивости. Тако би реплика у преводу, рецимо, могла гласити: „Молим вас, обраћајте ми се с дужним поштовањем. Ја сам за вас Иван Арнолдович!“". 
Овакво преводиочево решење изазива недоумице тим пре што је наредну реплику превео управо у духу објашњавања функције патронима: „Али и ви мене не ословљавате како треба!“ Будући да се имя и отчество понављају у обе реплике, односно постоји лексички паралелизам, једна од варијанти превода могла би да гласи: „Али ни ви мене не ословљавате с дужним поштовањем!“" или „Онда се и ви мени обраћајте с дужним поштовағем!“ Најзад, последња реплика у преводу гласи: „У мом стану ја нећу дозволити да вас ословљавају по имену и презимену по оиу“. Преводилац овде изоставља заменицу такомy на којој је заправо главни нагласак реплике. Ова заменица указује на конкретно име и патроним Полиграф Полиграфович које и лежи у основи спора око ословљавања: доктор и професор ословљавају Шарикова презименом не само зато што тако изражавају свој ниподаштавајући и нетрпељив став према њему, већ и зато што су им име и име по оцу, које је Шариков сам одабрао, чудни и одбојни, о чему је раније било речи у делу. У том смислу, ова реплика могла би бити преведена као: „Неће моћи! Не дозвољавам да вас у мом стану ословљавају са Полиграфе Полиграфовичу“. Напоменимо још да постоји и други превод овог романа на српски, чији је аутор М. Јовановић (Булгаков: 1971). У овом преводу у све три реплике као еквивалент отчества фигурира описна синтагма (критено и) очево име.

Аналошка замена лексеме отчество лексемом презиме, која је у претходно анализираном преводу неадекватна, може бити и сасвим прихватљива. Тако преводилац Чеховљеве приповетке Бегунац (Беглец), М. Пешић, у реченици: „У каждого фельдшер спрашивал имя и отчество, лета, местожительство, давно ли болен и проч." замењује ову лексему српским аналогом презиме: „Помоћник је свакога питао за име и презиме (...)“(Чехов 1961: 100). Ово можемо сматрати успелим решењем, тим пре што у наредној реченици фигурира управо дечаково презиме: „Из ответов своей матери Пашка узнал, что зовут его не Пашкой, а Павлом Галактионовым (...)“.

Губици у превођењу су неминовни - са тиме се слажу сви теоретичари превођења, тога су свесни и преводиоци. Упркос томе, преводилац треба да тежи преношењу што већег броја елемената садржаја текста оригинала, како оних денотативне природе, тако и оних конотативног карактера, како експлицитних, тако и имплицитних. У томе му помажу бројни преводилачки поступци које бира и комбинује. Основни поступак за преношење патронима остаје онај који се традиционално усталио - транскрипција, али не треба избегавати ни примену других поступака уместо транскрипције и, чешће, заједно с њом. Примена таквих поступака као што су функционална замена, аналошка замена, експликација, додавање, па чак и изостављање, омогућава преношење функција ове врсте антропонима у различитим текстовима.

У овом раду дотакли смо се тек једног проблема повезаног са преношењем властитих имена у преводу. За нека друга разматрања остају питања преношења тзв. аптронима (имена која одговарају природи или занимању личности која их носи, најчешће скована од стране аутора, нпр. Гогољев Башмачкин, Сјенкевичев Золзикјевич, Стеријин Смрдић и др.), алузивних имена (имена која асоцирају 
на књижевне или фолклорне ликове, пословице, фразеологизме и др. ${ }^{9}$, имена животиња (укључујући и традиционалне епитете животиња у фолклору - упор. нпр. лисичка-сестричка и тета лија), хипокористичко-деминутивних облика имена, надимака и слично.

\section{Цитирана литература}

Алексеева, Ирина С. Введениев переводоведение.СанктПетербург:Филологический факультет СПбГУ, Москва: Академия, 2004.

Бархударов, Леонид С. Язык и перевод. (Вопросы общей и частной теории перевода). Москва: Международные отношения, 1975.

Виноградов, Венедикт С. Введение в переводоведение (общие и лексические вопросы). Москва: Издательство института общего среднего образования РАО, 2001.

Влахов, Сергей, Флорин, Сидер. Непереводимое в переводе. Москва: Международные отношения, 1970.

Ермолович, Дмитрий И. Имена собственные на стыке языков и культур. Москва: Р. Валент, 2001

Комиссаров, Вилен Н. Современное переводоведение. Учебное пособие. Москва: ЭТС, 2002.

Лубас, Владислав. „Из проблематике превођења властитих назива“. Филолошки преглед I-II, 1970: 139-150.

Мачильская, Дарья О. Лексические средства организации начала художественного текста (на материале прозы А.П. Чехова). Диссертация на соискание ученой степени кандидата филологических наук, Саратов, 2018.

Маројевић, Радмило (уред.). Славистички зборник. Књига III. Транскрипција и превођење са словенских језика. Београд: Савез славистичких друштава СР Србије, 1988.

ОПП: Основные понятия переводоведения (Отечественный опыт). Терминологический словарь-справочник. М.Б. Раренко (отв. ред.). Москва: Российская академия наук. Институт научной информации по общественным наукам, 2010.

PCР: Руско-српскохрватски речник. Станковић, Богољуб (уред.). Москва: Русский язык, Нови Сад: Матица српска, 1988.

Сибиновић, Миодраг. Нови живот оригинала: увод у превођење. Београд: Просвета, Алтера, Удружење научних и стручних преводилаца, 2009.

Суперанская, Александра В. Общая теорија имени собственного. Москва: Наука, 1973.

DTS: Dictionary of Translation Studies. Mark, Shuttleworth, Moira, Cowie. New York: Routledge, 2014.

RHR: Rusko-hrvatski rječnik. Poljanec, Radoslav-Franjo, Madatova-Poljanec, Serafima

${ }^{9}$ Термин алузивна имена припада В. Виноградову који наводи пример јунака Ф.М. Достојевског Макара Девушкина којим се алудира на пословицу „На бедного Макара все шишки валятся“, а на коју директно упућује и сам писац у реплици свог јунака „Из моего имени пословицу сделали“ (Виноградов 178-179). 
M. 3. prerađeno i dopunjeno izdanje. Zagreb: Školska knjiga, 1973.

\section{Извори}

Булгаков, Михаил. Псеће срце. Београд: Нолит, 1971.

Гогољ, Николај В. Сабрана дела. 3. књ. Проповетке, Београд: Народна књига, Цетиње: Обод, 1970.

Достојевски, Фјодор М. Идиот. Београд: Отворена књига, 2006.

Толстој, Лав Н. Младост. Београд: Свесловенска књижарница М.J. Стефановића и друга, 1920.

Толстој, Лав Н. Сабрана дала Лава Николајевича Толстоја. Књ. 13. Васкрсење. Београд: Просвета-Рад, 1969.

Чехов, Антон П. Одабране приповетке. Београд: Нолит, 1961.

Чехов, Антон П. Приповетке. Београд: Просвета, 1966.

Bulgakov, Mihail. Pseće srce. Beograd: Lom, 2008

Gogolj, Nikolaj V. Pripovetke. Beograd, Zagreb: Kultura, 1948.

Dostojevski, Fjodor M. Bele noći, Kockar, Dvojnik. Beograd: Rad, 1977,

Dostojevski, Fjodor M. Zapisi iz mrtvog doma, Odvratna priča. Beograd: Rad, 1981

Solženjicin, Aleksandar. Jedan dan iz života Ivana Denisoviča. Beograd: Paideia, 2006. Tolstoj, Lav. Vaskrsenje. Beograd: izd. Branko Đonović, 1964.

\section{Милена Иванович}

\section{ПРОБЛЕМЫ ПЕРЕВОДА ИМЕН СОБСТВЕННЫХ: ОТЧЕСТВА (на материале русского языка)}

\section{Резюме}

В статье рассматриваются проблемы перевода на сербский язык восточнословянских отчеств, которые представляют своеобразные реалии. Проанализированы существующие переводы, в которых, как правило, применяется транскрипция, а также представлены возможности применения других приемов, таких как: функциональная замена, экспликация, переводческий комментарий, добавление и др. Применение этих трансформаций подразумевает определенную прагматическую адаптацию, но, с другой стороны, позволяет передавать различные функции отчеств в тексте, в первую очередь эмоциональную, и различные элементы их содержания, прежде всего конотативные, с целью достижения максимальной эквивалентности текста оригинала и текста перевода. Часть статьи посвящена проблемам перевода самой лексемы отчество.

Ключевые слова: отчество, реалия, идентификационная функция, эмоциональная функция, транскрипция, прагматическая адаптация, функциональная замена, экспликация, переводческий комментарий, добавление. 